\title{
Capital structure of small companies in the Spanish footwear sector: relevant factors
}

\author{
Miguel A. Acedo-Ramírez • Juan C. Ayala-Calvo • \\ José E. Rodríguez-Osés
}

Received: 24 November 2010 / Accepted: 7 February 2012 / Published online: 24 February 2012

(C) The Author(s) 2012. This article is published with open access at SpringerLink.com

\begin{abstract}
This study suggests the preponderance of the pecking order theory over the trade-off theory when there are greater problems of information asymmetry, which is more usual in small-sized firms. The results show that debt level has an inverse relationship with non-debt tax shield and direct relationship with investment in fixed assets, supporting the trade-off theory. However, the positive coefficient of growth opportunities and negative coefficient of debt cost, age and cash flows is consistent with the prediction of the pecking order theory. Results taken from a sample of small Spanish companies in the footwear sector during the period 1998-2006, revealed that in absence of asymmetric information, firms with positive cash flows will prefer debt because (a) they want to maintain their optimal capital structure; (b) they have greater needs to shield this cash flow from corporate tax and (c) they are concerned about the problem of over-investments, which means that they issue debt in order to discipline the firm's managers. The relationship between growth opportunities and debt level was positive. This is not surprising due to the need to finance these investment opportunities with debt, because rapidly growing firms are likely to have insufficient earnings to finance internally all of their growth. Furthermore, the low debt level of companies in the Spanish footwear sector also helps to explain this relationship due to the importance of R\&D investments for this industry, which lenders value as strategic investments. Finally, small businesses face high transaction costs derived from typical agency problems and financial restriction on capital markets. Such high transaction costs justify the gap between the target and the current debt level and are responsible for the slow approach of their debt level to the target ratio.
\end{abstract}

M. A. Acedo-Ramírez $(\varangle)$ · J. C. Ayala-Calvo · J. E. Rodríguez-Osés

Dpto. Economía y Empresa, Universidad de La Rioja, C/Cigüeña 60,

26004 Logroño, La Rioja, Spain

e-mail: miguel-angel.acedo@unirioja.es 
Keywords Capital structure · Non-debt tax shield · Growth opportunities ·

Cash flow

\section{JEL Classification G32}

\section{Introduction}

The financial structure of companies and its influence on the value of company stock has been a recurring theme in financial literature since the late 1950s. However, despite the huge number of studies published on this subject, there is still no consensus among academics on whether an optimal financial structure actually exists or on the factors that influence this financial structure. Modigliani and Miller (1958) and Miller (1977) claimed that the market value of a company is independent of its financial structure. Modigliani and Miller (1963), when examining the influence of corporate income tax on capital structure, concluded that due to fiscal deductibility of interest, the market value of an indebted company must be greater than that of the same company without debts. Deangelo and Masulis (1980) argued that companies that enjoy non-debt tax shields (NDTSs) have fewer incentives to become indebted. Two main theories currently dominate the capital structure debate: the trade-off theory and the pecking order theory.

The trade-off theory (Myers 1984) supports the existence of an optimal capital structure, an optimal debt ratio that is determined by the contrasting benefits of debt (tax shield, disciplinary role of debt, reduction of free cash flow problems and the fact that debt suffers less from informational costs than outside equity) and the cost of debt (financial distress costs and the agency costs between shareholders and bondholders) (Jalilvand and Harris 1984; Frank and Goyal 2000).

However, according to the pecking order theory (Myers and Majluf 1984), the existence of information asymmetry between the company and the market means that managers prefer to finance projects with internally generated funds (retained earnings or cash-flows), which involve no asymmetric information problems, rather than resorting to external financing. If they need external funds, they prefer debt to equity in order to reduce the information asymmetry. Thus, there is a preference ranking over financing sources, beginning with internal funds, followed by debt and finally by equity.

Both financial structure theories are not mutually exclusive but rather it is considered that the pecking order theory is embedded within the trade-off theory. The pecking order theory is based on the existence of information asymmetry, which is just one of the costs considered by the trade-off theory. Empirical evidence shows the partial validity of both theories but differs in specifying which theory is the prevailing one. This dialectic controversy between the trade-off theory and the pecking order theory, fuelled by the importance that different authors have attributed to the variables used to explain company leverage, could be due to various causes as well, which are sometimes inter-related:

(a) The size of the companies included in samples. Most research on capital structure has been performed with samples of large publicly listed companies 
(Shyam-Sunder and Myers 1999; Fama and French 2002; De Miguel and Pindado 2001). Very few studies have focused on small and medium-sized firms (Cassar and Holmes 2003; Sogorb 2005). Small firms often suffer the problems associated with asymmetric information when they seek new financing (Ang 1992). In this sense, they seem to be affected by the typical problems analysed by the pecking order theory. However, these companies could also have a target debt level to guide their financial policy, as indicated by the trade-off theory.

(b) The different institutional frameworks of the countries where firms obtain revenues. Many studies on financial structure have focused on companies that obtain their revenues in financial systems based on the Anglo-Saxon system. The few studies on non-American companies include those by Rajan and Zingales (1995), Wald (1999), and Mcclure et al. (1999), who analysed samples of companies based in G7 countries. The results of these studies showed that the different institutional frameworks of the different countries can affect companies' capital structures. Certainly, there is not enough evidence on how theories formulated for firms operating in major developed markets can be applied to firms outside these markets, and in countries with different institutional and legal environments.

(c) The methodology used in research. Most research faces two problems: it does not shed any light on the adjustment process of capital structure and they use statistical methods to check the different hypotheses presented that do not take into account the presence of unobservable heterogeneity, which refers to omitted variables that affect the outcome of interest and are correlated with the covariates. In regards to the adjustment process in our model, it should be said that capital structure decisions are dynamic by nature and should be modelled as such. Companies try to adjust their debt levels to the desired objective. In this study, we used a target adjustment model to explain current debt according to past debt and the firm's target debt level; the latter included in the model as a linear function of the factors determining capital structure (Lööf 2004; Gaud et al. 2005; González and González 2007). If there is a target debt level, then firms should take appropriate steps to reach this objective. But the existence of transaction costs means that companies do not automatically adjust their levels of indebtedness to the target level. We used this to obtain a dynamic model with predetermined variables, estimated using the Generalized Method of Moments, which allowed us to solve endogeneity problems by using instruments. In regards to the second problem, in this work, by using panel data methodology we also took into account unobservable heterogeneity since the companies had different characteristics that were difficult to observe, obtain or measure.

(d) Finally, most empirical studies of financial structure have been performed using samples without specifying the sectors to which the companies pertained. That approach has one drawback, namely that the specific characteristics of such diverse branches of activity are diluted in the overall results obtained. We felt it was better to perform a more in-depth study of one of the most interesting industries (the footwear sector) because the general results obtained in other papers did not necessarily have to coincide with those of specific sectors. It would be reasonable to suppose that specific characteristics of a given industry could also 
Table 1 Spanish footwear industry

\begin{tabular}{lllllllll}
\hline & 2000 & 2001 & 2002 & 2003 & 2004 & 2005 & 2006 & 2007 \\
\hline $\begin{array}{l}\text { No. of } \\
\text { companies }\end{array}$ & 34.347 & 34.237 & 34.679 & 34.013 & 33.301 & 31.941 & 29.652 & 28.414 \\
$\begin{array}{c}\text { Industrial } \\
\text { GDP }(€)\end{array}$ & $7,443,000$ & $7,397,000$ & $6,936,210$ & $6,913,352$ & $6,404,026$ & $5,960,293$ & $5,859,860$ & $5,636,930$ \\
$\begin{array}{c}\text { Industrial } \\
\text { GDP }(\%)\end{array}$ & 7.20 & 6.93 & 6.51 & 6.41 & 5.90 & 5.44 & 5.19 & 4.85 \\
$\begin{array}{c}\text { Profit margin }= \\
\text { EBIT/sales } \\
(\%)\end{array}$ & 3.04 & 2.43 & 2.17 & 2.10 & 2.49 & 0.87 & 1.50 & 1.44 \\
Debt level $(\%)$ & - & - & - & 26.14 & 27.88 & 28.49 & 28.89 & 28.96 \\
\hline
\end{tabular}

The debt ratio is measured as the ratio between the book value of long-term debt and the book value of equity plus the book value of long-term debt

Source: National Institute of Statistics and Iberian Balances Analysis System SABI

influence the capital structure of the firm (Kayo and Kimura 2010). Ross et al. (2008) and Lemmon et al. (2008) point to inter-industry differences in debt ratios. Frank and Goyal (2009) find that industry leverage is an important determinant of firm leverage.

In this paper we study the footwear sector for different reasons: according to the Spanish Footwear Federation, Spain is the second footwear producing and exporting country in the European Union and the footwear sector is one of the industries which is most open to foreign markets. The footwear sector generates $0.76 \%$ of Spanish GDP at market prices, employs $0.23 \%$ of the working population and represents $0.80 \%$ of gross investment in assets. It is an old activity that has almost disappeared in some European countries like Germany or France, and is currently undergoing a process of reorganisation and permanent reinvention in Spain and Italy. Specifically, the weight of this sector in the Industrial GDP of Spain has decreased $18.95 \%$ in the period 2005-2007 (see Table 1).

The Spanish footwear industry is highly competitive, has a low level of indebtedness and is a strong investor in innovation. These factors can influence the relationship between the level of indebtedness and some of the explanatory variables. One of the variables most commonly used to measure the degree of rivalry between industries is the adjustment between supply and demand in each sector. The adjustment in the demand can be approximated by the change in GDP, while the adjustment of supply is usually measured (among other variables) through the variation in capacity (number of companies) or modification of exit barriers (mortality of enterprises). The footwear industry is the only sector in Spain whose GDP has decreased in recent years. In the period 2000-2007, the GDP of the footwear industry has fallen approximately $24.27 \%$, while the number of firms has declined only $17.27 \%$ (see Table 1). This mismatch, which means an increase in industry rivalry, is evident when looking at the decline in the profit margins of the period analysed $(-52.5 \%)$. Furthermore, the average level of indebtedness of the footwear industry in the period 2003-2007 (28.07\%) is below the average for Spanish industry as a whole (31.06\%) (see Table 1). More specifically, it is one of the 10 sectors with the lowest level of indebtedness in Spain. Moreover, 
according to data obtained in the Business Strategies Survey, the footwear industry is the leading industry in terms of investment in product innovation. The investment in product innovation quantifies the effort in the development of new products or changes in the products, which are so important that the new versions are completely different from the original ones (use of new materials, new components, new design and presentation, new features, new uses, etc.). Given the important challenges facing this sector (need to operate and compete in increasingly globalised markets, need to be continually innovative in products and processes, need to achieve a minimum size in order to achieve economies of scale, outsourcing, etc.), having a balanced financial structure that provides the necessary funds at the lowest possible cost is a key for the survival and success of companies in this sector.

Taking into account the above-mentioned reasoning, it is important to highlight that this research, unlike previous studies, was conducted with a sample of small businesses from the footwear sector that obtained financing exclusively in the Spanish market, and that we used the panel data methodology to take into consideration the unobservable heterogeneity. This paper focuses on small Spanish businesses financing, as this type of company represents a large proportion of total companies in the economy. Most of the research on capital structure of Spanish small and medium enterprises (SMEs) had been essentially descriptive (Maroto 1996; López and Romero 1997) or the firm sample did not specify the sectors to which the companies pertained (Sogorb 2005; López and Sogorb 2008). Acedo and Rodríguez (2003) analysed the debt level of the footwear industry only in the autonomous community of La Rioja. Using an analysis of variance, they analyzed whether the debt level differed between the footwear and agriculture industries, the latter being the main sector in La Rioja. Much more recently, studies of financial structure in small Spanish firms have incorporated different estimation techniques such as the analysis of variance (López and Aybar 2000; Acedo and Rodríguez 2003) and panel data estimation, using a static (Sogorb 2005) or a dynamic linear model (López and Sogorb 2008).

Our study presents five main differences from those references cited before for the Spanish context: (a) it employs a sample of small firms and an objective definition of small companies that is valid for the European Union, (b) the firm sample covers one important activity (the footwear industry) in the Spanish economy in more than one Autonomous Community, as is the case in Acedo and Rodríguez (2003), (c) it increases the number of theoretical hypotheses considering other variables such as debt cost and age, (d) it provides evidence of the influence of the asymmetric information variable in the relationship between cash flow and debt level, and (e) it applies the panel data methodology in the estimation of a dynamic linear model allowing for individual heterogeneity and time effects. This technique allows us to study the speed of adjustment of small Spanish footwear firms toward their capital structure target.

Following this line of research, we aim to obtain the main determinants of capital structure in small Spanish footwear businesses from the perspective of the two financial approaches mentioned above. More specifically, we ask the following questions: Can the type of relationship between indebtedness and the main variables that influence capital structure proposed in previous work be maintained for a small sample of Spanish companies in the footwear industry? What is the relationship and the importance of the variables (NDTS, growth opportunities, tangibility of assets, debt cost, 
age and cash flow) in explaining the financial structure of the small, Spanish, footwear business?

Our results provide empirical evidence of the predominance of the pecking order theory over the trade-off theory in the explanation of the capital structure of small Spanish footwear firms. We provide evidence of the higher transaction cost (lower speed of adjustment) of the small Spanish footwear firms. Growth opportunities showed a significant direct relationship with leverage, due to (a) the need to finance these investment opportunities which, ceteris paribus, will lead to the use of more debt, (b) the low level of indebtedness of Spanish footwear firms and the importance of R\&D investments in this sector. Finally, the results show that when asymmetric information is not important, profitable firms tend to issue more debt in order to limit over-investment and maintain their optimal capital structure by reducing the amount of taxes they pay.

The article is divided into six sections. Section 2 summarises previous studies on capital structure. Section 3 describes the database and defines the variables used in the study. Sections 4 and 5 present the econometric specification of the model and the empirical evidence. Section 6 presents the main conclusions that can be drawn from the analysis.

\section{Determinants of capital structure: trade-off versus pecking order}

\subsection{Non-debt tax shield}

As predicted by the trade-off theory, a major motivation for using debt instead of equity is to save corporate tax. However, firms can use NDTSs in order to pay fewer taxes. Deangelo and Masulis (1980) affirm that companies with larger NDTSs, ceteris paribus, are less indebted. These companies have less need to issue debt in order to take advantage of interest tax deductions because they already enjoy tax benefits. Taxes are still relevant even when we are only considering a particular sector because even though all companies in this sector have the same tax system, what we are really looking at is whether the existence of NDTSs (amortization, investment tax credits, job creation credits, etc.) influences the level of that debt. Most empirical evidence confirms an indirect relationship between NDTSs and debt level (Wald 1999; Sogorb 2005; Huang and Song 2006). Taking into consideration the above-mentioned reasoning, we proposed the following hypothesis:

$\mathrm{H} 1$ : an inverse relationship is expected between debt level and NDTSs.

\subsection{Growth opportunities}

One of the determinants of capital structure is the existence of growth opportunities. The trade-off theory predicts that investment opportunities are generally associated with less leverage, given that greater investment opportunities: (a) are associated with a lower free cash flow and less need for the disciplinary role of debt over manager behaviour (Jensen 1986), (b) have more agency conflicts between stockholders and lenders because shareholders have greater possibilities of risk-shifting substitution (Myers 1977). Furthermore, financial distress cost increases with growth opportuni- 
ties. Growth opportunities lose substantial value in the event of bankruptcy; hence lenders, since they have fewer guarantees, react by providing the company with less financing, and charge larger risk premiums on the cost of debt (Frank and Goyal 2009. Different empirical works have found an inverse relationship between growth opportunities and debt (Huang and Song 2006; Kayo and Kimura 2010). Thus, we proposed the following hypothesis.

$\mathrm{H} 2 \mathrm{a}$ : an inverse relationship is expected between growth opportunities (GO) and debt level.

However, the pecking order theory predicts a direct relationship between leverage and growth opportunities (Frank and Goyal 2009). Rapidly growing firms are likely to have insufficient earnings to finance all of their growth internally and they will seek external financing. Growth is likely to put a strain on retained earnings and push the firm into borrowing (Myers 1984; Michaelas et al. 1999). Between the empirical papers that find a direct relationship between growth opportunities and leverage we have De Miguel and Pindado (2001), Goyal et al. (2002), Murray and Goyal (2003), Sogorb (2005) and Casson et al. (2007). Following this line of reasoning, the hypothesis could be established as:

$\mathrm{H} 2 \mathrm{~b}$ : a direct relationship is expected between growth opportunities $(\mathrm{GO})$ and debt level.

\subsection{Tangibility of assets}

According to the trade-off theory, tangible assets have an impact on debt because, if a large fraction of a firm's assets are tangible assets, then the assets should serve as collateral, thus diminishing the lender's risk of suffering the agency costs deriving from debt (Frank and Goyal 2009). It is therefore expected that a positive relationship exists between tangibility and leverage (Booth et al. 2001; Huang and Song 2006; Frank and Goyal 2009; Céspedes et al. 2010; Chakraborty 2010; Kayo and Kimura 2010). Therefore, based on the aforementioned theoretical framework, we propose the hypothesis:

H3a: a direct relationship is expected between investment in fixed assets (I) and debt level.

However, from the perspective of the pecking order theory, firms with more tangible assets are less subject to information asymmetries and will therefore issue equity rather than debt when they need external financing (Harris and Raviv 1991; González and González 2007; Frank and Goyal 2009). Therefore, this theory predicts a inverse relationship between the analysed variables.

$\mathrm{H} 3 \mathrm{~b}$ : an inverse relationship is expected between investment in fixed assets (I) and debt level.

\subsection{Debt cost}

The interest rate can influence the financial structure. According to the trade-off theory, an increase of the interest rate makes the debt more attractive because it provides greater potential for tax deduction (Taggart 1985). Thus, there is a direct relationship 
between leverage and debt cost. This relationship is confirmed by different empirical papers (Bougheas et al. 2006; Frank and Goyal 2009). The proposed hypothesis is:

$\mathrm{H} 4 \mathrm{a}$ : a direct relationship is expected between the interest rate (IN) and debt level.

However, according to the pecking order theory, managers have a preference for issuing debt when interest rates are low or when interest rates are expected to increase (Van Horne 1977; Graham and Harvey 2001). When interest rates are low, firms take advantage in order to increase their leverage (Cuñat 1999; Barry et al. 2008). Then, an inverse relationship it is expected between debt cost and leverage. This kind of relationship is found in different papers (Cuñat 1999; Barry et al. 2008). The proposed hypothesis is:

$\mathrm{H} 4 \mathrm{~b}$ : an inverse relationship is expected between the interest rate (IN) and debt level.

\subsection{Age}

The trade-off theory predicts that older firms not only face less bankruptcy problems and lower agency costs but that they are also more established, have a better reputation, credit history and a greater tendency to choose safe investment projects (Diamond 1989; López and Sogorb 2008; Frank and Goyal 2009). By contrast, younger firms will have a greater tendency to choose riskier projects. The implication is that there is a direct relationship between age and the debt level. Boot (2000) and Bougheas et al. (2006) find empirical evidence in favour of this relationship:

H5a: a direct relationship is expected between age (AG) and debt level.

However, according to the pecking order theory, more mature companies tend to have higher cash flow generated internally over the years, so a lower debt level is expected. On the contrary, younger firms cannot retain earnings as easily as older firms can (Myers and Majluf 1984; López and Sogorb 2008; Frank and Goyal 2009). We find empirical evidence in favour of this kind of relationship (Michaelas et al. 1999; Hall and Graham 2000; López and Sogorb 2008).

H5b: an inverse relationship is expected between age (AG) and debt level.

\subsection{Cash flow or profitability}

According to the pecking order theory, managers prefer internal to external financing because cash flow generated internally is not affected by problems of information asymmetry between manager and outside investors. If they need external financing, they prefer debt over equity. Thus, there is a preference ranking over financing sources, beginning with internal funds, followed by debt and finally by equity. Therefore, we should expect a negative relationship between debt and cash-flow.

Nevertheless, the trade-off theory (Myers 1984) suggests a direct relationship between debt and cash flow. According to the trade-off theory, when firms are profitable, they should prefer debt in order to maintain their optimal capital structure and because they have greater needs to shield this cash flow from corporate tax. In addition, firm's managers with free cash flow tend to invest in projects with a negative net present value (over investment problem). One possible solution for this problem is the 
issuing of debt forcing the payment of interest. Debt mitigates agency costs associated with an excess cash flow and disciplines the firm's managers (Jensen 1986).

Most previous empirical studies have identified an inverse relationship between cash flow and indebtedness (Giannetti 2003; Chen 2004; Huang and Song 2006; Frank and Goyal 2009; Céspedes et al. 2010; Chakraborty 2010; Kayo and Kimura 2010). Barton et al. (1989) and Jensen et al. (1992) show a positive relationship.

Consequently, in the presence of asymmetric information and agency problems, we propose two hypotheses:

H6a: an inverse relationship is expected between cash flow and debt level.

H6b: a direct relationship is expected between cash flow and debt level.

Table 2 summarises the relationship postulated by the theory between each explanatory variable and leverage.

\section{Database description and variable definition}

Our database was created using individualized public information (standardised balance sheets and income statements) that Spanish companies from the footwear sector are required to submit to the Mercantile Registry for the period 1998-2006. This information was obtained from the Sistema de Análisis de Balances Ibéricos (SABI) database which is managed by Grupo Informa S.A. and Bureau Van Dyck and purports to represent more than $95 \%$ of the Spanish companies. The firms in the sample meet the definition established by the European Union for small businesses (recommendation 2003/361/EC): <50 workers and an annual turnover or assets below 10 million euros. The initial sample consisted of all the Spanish small companies pertaining to section 193 Footwear Manufacture of the National Classification of Economic Activities (CNAE-93) for which data were available for all variables for at least on year in the period analysed (861 firms). Given the usual requirements of dynamic panel data models and in order to avoid problems of unobservable heterogeneity and endogeneity, we constructed an unbalanced data panel comprising 299 companies for which information was available for at least three consecutive years between 1998 and 2006. As a result, we obtained an unbalanced panel, whose structure by number of observations per company is shown in Table 3.

In this study we use book values for the variables because information about market values was unavailable as the sample is composed of small unlisted companies. The variables used in the model explaining capital structure were:

Debt ratio (D), measured as the ratio between the book value of long-term debt and the book value of equity plus the book value of long-term debt: $D_{\text {it }}=$ Long term $\mathrm{debt}_{\mathrm{it}} /$ Equity $_{\mathrm{it}}+$ Long term debt $\mathrm{it}_{\mathrm{it}}$ (De Miguel and Pindado 2001). The advantage of measuring debt this way is that it is the most stable way to measure leverage. This measure of leverage is more fixed and arguably more deliberate, with greater contractual obligations and screening processes required (Cassar and Holmes 2003).

Non-debt tax shield has been defined in the majority of papers as the depreciation and amortization expenses (Bradley et al. 1984; Wald 1999; Chaplinsky and Niehaus 1993; Deesomsak et al. 2004). However, amortization and depreciation expenses are 
Table 2 Theories and expected relationships between corporate factors and firm leverage

\begin{tabular}{|c|c|c|c|c|}
\hline Variable & $\begin{array}{l}\text { Expected } \\
\text { theoretical } \\
\text { relationship }\end{array}$ & Trade-off theory & $\begin{array}{l}\text { Expected } \\
\text { theoretical } \\
\text { relationship }\end{array}$ & $\begin{array}{l}\text { Pecking order } \\
\text { theory }\end{array}$ \\
\hline NDTS & - & $\begin{array}{l}\text { Companies with larger } \\
\text { non-debt tax shields, ceteris } \\
\text { paribus, have less need to } \\
\text { issue debt in order to take } \\
\text { advantage of interest tax } \\
\text { deductions because they } \\
\text { already enjoy tax benefits }\end{array}$ & & \\
\hline GO & - & $\begin{array}{l}\text { Greater growth opportunities: } \\
\text { (a) are associated with a } \\
\text { lower free cash flow and } \\
\text { less need for the } \\
\text { disciplinary role of debt, (b) } \\
\text { have more agency conflicts } \\
\text { between stockholders and } \\
\text { lenders and (c) increase } \\
\text { financial distress cost }\end{array}$ & + & $\begin{array}{l}\text { Rapidly growing firms are } \\
\text { likely to have insufficient } \\
\text { earnings to finance all of } \\
\text { their growth internally and } \\
\text { they will seek external } \\
\text { financing. Growth is likely } \\
\text { to put a strain on retained } \\
\text { earnings and push the firm } \\
\text { into borrowing }\end{array}$ \\
\hline I & + & $\begin{array}{l}\text { If a large fraction of a firm's } \\
\text { assets are tangible assets, } \\
\text { then the assets should serve } \\
\text { as collateral, thus } \\
\text { diminishing the lender's } \\
\text { risk of suffering the agency } \\
\text { costs derived from debt }\end{array}$ & - & $\begin{array}{l}\text { Firms with more tangible } \\
\text { assets are less subject to } \\
\text { information asymmetries } \\
\text { and will therefore issue } \\
\text { equity rather than debt }\end{array}$ \\
\hline IN & + & $\begin{array}{l}\text { An increase of the interest } \\
\text { rate makes debt more } \\
\text { attractive because of its } \\
\text { greater potential for tax } \\
\text { deduction }\end{array}$ & - & $\begin{array}{l}\text { Managers have a preference } \\
\text { for issuing debt when } \\
\text { interest rates are low or } \\
\text { when interest rates are } \\
\text { expected to increase }\end{array}$ \\
\hline $\mathrm{AG}$ & + & $\begin{array}{l}\text { Older and more established } \\
\text { firms, with more credit } \\
\text { history, have a greater } \\
\text { tendency to choose safe } \\
\text { investment projects }\end{array}$ & - & $\begin{array}{l}\text { More mature companies tend } \\
\text { to have higher cash flow } \\
\text { generated internally over } \\
\text { the years, so a lower debt } \\
\text { level is expected }\end{array}$ \\
\hline $\mathrm{CF}$ & + & $\begin{array}{l}\text { Firms should prefer debt (a) } \\
\text { in order to maintain their } \\
\text { optimal capital structure, } \\
\text { (b) because they have } \\
\text { greater needs to shield this } \\
\text { cash flow from corporate } \\
\text { tax, and c) to discipline the } \\
\text { firm's managers }\end{array}$ & - & $\begin{array}{l}\text { Managers prefer to finance } \\
\text { projects internally because } \\
\text { of the information } \\
\text { asymmetry between } \\
\text { manager and outside } \\
\text { investors }\end{array}$ \\
\hline
\end{tabular}

"+" means that leverage increases with the factor, "-" means that leverage decreases with the factor

highly correlated with tangibility, which is also expected to affect the leverage of firms. In order to avoid this problem, we will measure the NDTSs as the difference between earnings before taxes and the results of taxes paid divided by the tax rate (Titman and Wessels 1988; De Miguel and Pindado 2001; González and González 2007): NDTS $_{i t}=\left(\right.$ EBT $_{i t}-($ Taxes paid $/$ Tax rate it $\left.)\right) / K_{i t}$. Therefore, the variable 
Table 3 Structure of the sample

\begin{tabular}{lcc}
\hline Number of annual observations per company & Number of companies & Number of observations \\
\hline 3 & 142 & 426 \\
4 & 88 & 352 \\
5 & 22 & 110 \\
6 & 21 & 126 \\
7 & 18 & 126 \\
8 & 6 & 48 \\
9 & 2 & 18 \\
Total & 299 & 1,206 \\
\hline
\end{tabular}

Data of companies for which the information is available for at least three consecutive years, between years 1998-2006, have been extracted. The resultant unbalanced panel comprises 299 Spanish companies (1,206 observations)

includes those quantities of earnings that were not taxed due to the existence of NDTSs.

Growth opportunities (GO) have been measured with different proxies. Wald (1999) and López and Sogorb use the average of sales growth. Rajan and Zingales (1995) use Tobin's Q (market-to-book ratio of total assets) and Booth et al. (2001) use the marketto-book ratio of equity. We argue that sales growth rate is the past growth experience, while the other two proxies are better measures for growth. But because none of our sample firms are listed in a stock exchange, we use the ratio between intangible assets and total assets (Bradley et al. 1984; Titman and Wessels 1988; Michaelas et al. 1999): $\mathrm{GO}_{\text {it }}=$ intangible assets $\mathrm{it}_{\mathrm{it}} / \mathrm{K}_{\mathrm{it}}$.

Investments (I) were measured as the ratio of the difference between net fixed assets in the current and previous periods, plus depreciation expenditure in the current period divided by total assets (Lewellen and Badrinath 1997; De Miguel and Pindado 2001): $\mathrm{I}_{\mathrm{it}}=\left(\mathrm{NFA}_{\mathrm{it}}-\mathrm{NFA}_{\mathrm{it}-1}+\right.$ Depreciation $\left._{\mathrm{it}}\right) / \mathrm{K}_{\mathrm{it}}$.

Debt cost (IN) is measured by the ratio of financial expenses between the total debts (Cuñat 1999; Barry et al. 2008).

Age (AG) is measured by time elapsed between the creation date and the current year (Michaelas et al. 1999; Hall and Graham 2000; López and Sogorb 2008).

Cash flow $(\mathrm{CF})$ was the ratio of the addition of earnings before interest and taxes (EBIT) and non-cash deductions (depreciations and provisions) divided by total assets: $\mathrm{CF}_{\mathrm{it}}=\left(\mathrm{EBIT}_{\mathrm{it}}+\right.$ Depreciation $_{\mathrm{it}}+$ Provisions $\left._{\mathrm{it}}\right) / \mathrm{K}_{\mathrm{it}}($ De Miguel and Pindado 2001).

Asymmetric information (AI) was measured as the proportion of tangible fixed assets and intangible assets. The presence of intangible assets reveals greater problems of asymmetric information than tangible assets. A factor analysis with principal components was performed using the variables of tangible fixed assets and intangible assets (De Miguel and Pindado 2001). The coordinates of these variables on the first factorial axis were 0.2190 and -0.2190 for tangible fixed assets and intangible assets, respectively, the Eigen value being 0.09590 (difference is 0.17627 , proportion 6.1730 and cumulative 6.1730).

Therefore, we constructed a factor that would be positive when the company had a high proportion of tangible fixed assets and, consequently, fewer problems of asymmetric information. This factor would be negative if intangible assets were the main 
Table 4 Statistic summary of the dependent and independent variables

\begin{tabular}{lllll}
\hline & Mean & Standard deviation & Minimum & Maximum \\
\hline $\mathrm{D}_{\text {it }}$ & 0.3110 & 0.2376 & 0.0004 & 0.8925 \\
NDTS $_{\text {it }}$ & 0.00198 & 0.0232 & -0.2198 & 0.2132 \\
$\mathrm{GO}_{\text {it }}$ & 0.0457 & 0.0698 & 0 & 0.5648 \\
$\mathrm{I}_{\mathrm{it}}$ & 0.0603 & 0.0782 & -0.5411 & 0.5516 \\
$\mathrm{IN}_{\text {it }}$ & 0.0630 & 0.1369 & 0 & 0.2931 \\
$\mathrm{AG}_{\text {it }}$ & 11.88 & 6.0207 & 4 & 46 \\
$\mathrm{CF}_{\text {it }}$ & 0.0954 & 0.0617 & -0.0111 & 0.5198 \\
Employees & 19.2 & 8.4 & 10 & 50 \\
\hline
\end{tabular}

This table presents descriptive statistics for the variables used in our estimations. $\mathrm{D}_{\mathrm{it}}$ denotes the ratio of the book value of long-term debt and the book value of equity plus the long-term debt; NDTS it $_{\text {denotes the }}$ non-debt tax shield measure as the ratio of the difference between earnings before taxes and the results of taxes paid divided by the tax rate; $\mathrm{GO}_{\mathrm{it}}$ denotes the growth opportunities measure as the intangible assets to total assets; $\mathrm{I}_{\mathrm{it}}$ denotes the investment in net fixed assets measure as the ratio of the difference between net fixed assets in the current and previous periods, plus depreciation expenditure in the current period divided by total assets, $\mathrm{IN}_{\mathrm{it}}$ denotes the debt cost measure as the ratio of financial expenses between total debts, $\mathrm{AG}_{\mathrm{it}}$ denotes the firm age, measure by the time elapsed between the creation date and the current year and $\mathrm{CF}_{\text {it }}$ denotes the cash flow measure as the ratio of the addition of earnings before interest and taxes and non-cash deductions (depreciations and provisions) divided by total assets

assets and there would therefore be greater problems of asymmetric information. Starting with this factor, we constructed a dummy variable- $\mathrm{AI}_{\mathrm{it}}$ - which took the value 1 when the factor was positive (therefore, predominately tangible fixed assets) and zero when the factor was negative (therefore, predominately intangible assets). This variable interacted with cash flow in order to determine the sensitivity of indebtedness to cash flow in the presence or absence of asymmetric information.

Table 4 shows the descriptive results of the level of indebtedness and its explanatory variables, as well as the number of employees.

\section{Econometric specification of the model}

According to the theoretical framework described above, the target debt level of a firm may be explained by the NDTSs, growth opportunities, investments, debt cost, age and cash flow.

$$
\begin{aligned}
\mathrm{D}_{\mathrm{it}}^{*}= & \beta_{1}+\beta_{2} \cdot \mathrm{NDTS}_{\mathrm{it}}+\beta_{3} \cdot \mathrm{GO}_{\mathrm{it}}+\beta_{4} \cdot \mathrm{I}_{\mathrm{it}} \\
& +\beta_{5} \cdot \mathrm{IN}_{\mathrm{it}}+\beta_{6} \cdot \mathrm{AG}_{\mathrm{it}}+\beta_{7} \cdot \mathrm{CF}_{\mathrm{it}}+\varepsilon_{\mathrm{it}}
\end{aligned}
$$

The existence of transaction costs means that companies do not automatically adjust their levels of indebtedness to the target level, therefore:

$$
\mathrm{D}_{\mathrm{it}}-\mathrm{D}_{\mathrm{it}-1}=\alpha \cdot\left(\mathrm{D}_{\mathrm{it}}^{*}-\mathrm{D}_{\mathrm{it}-1}\right), \quad 0<\alpha<1
$$

where $\mathrm{D}_{\mathrm{it}}$ and $\mathrm{D}_{\mathrm{it}-1}$ are the actual debt levels in the current and previous period, respectively. $\mathrm{D}_{\text {it }}^{*}$ is the target debt level and $\alpha$ measures the adjustment speed. Transaction costs are inversely related to $\alpha$ and can be referred to as $1-\alpha$. If the adjustment 
speed is very high $\alpha=1$, the companies automatically adjust their indebtedness level to the targeted level of indebtedness $\mathrm{D}_{\mathrm{it}}=\mathrm{D}_{\mathrm{it}}^{*}$. If, in contrast, the speed of adjustment is null $\alpha=0$, companies prefer to do nothing $\mathrm{D}_{\mathrm{it}}=\mathrm{D}_{i t-1}$. When the speed of adjustment is at an intermediate level $0<\alpha<1$, companies adjust their indebtedness level to the target debt level in a direct manner as to adjustment speed.

Equation 2 provides the current level of indebtedness:

$$
\mathrm{D}_{\mathrm{it}}=\alpha \cdot \mathrm{D}_{\mathrm{it}}^{*}+(1-\alpha) \cdot \mathrm{D}_{\mathrm{it}-1}
$$

By integrating Eqs. 1 and 3, and bearing in mind that we are working with panel data, we obtained model I:

$$
\begin{aligned}
\mathrm{D}_{\mathrm{it}}= & \alpha \cdot \beta_{1}+(1-\alpha) \cdot \mathrm{D}_{\mathrm{i}, \mathrm{t}-1}+\alpha \cdot \beta_{2} \cdot \mathrm{NDTS}_{\mathrm{it}}+\alpha \cdot \beta_{3} \cdot \mathrm{GO}_{\mathrm{it}}+\cdot \beta_{4} \cdot \mathrm{I}_{\mathrm{it}} \\
& +\alpha \cdot \beta_{5} \cdot \mathrm{IN}_{\mathrm{it}}+\alpha \cdot \beta_{6} \cdot \mathrm{AG}_{\mathrm{it}}+\alpha \cdot \beta_{7} \cdot \mathrm{CF}_{\mathrm{it}}+\mathrm{d}_{\mathrm{t}}+\eta_{\mathrm{i}}+\varepsilon_{\mathrm{it}}
\end{aligned}
$$

where $d_{t}$ is the time-specific or temporal effect (effect of macroeconomic variables on capital structure), $\eta_{\mathrm{i}}$ is the firm-specific effect (to control for unobservable heterogeneity) and $\varepsilon_{\text {it }}$ is a white noise or random disturbance.

Equation model (4) can be modified taking into account the influence of the existence of asymmetric information on cash flow. The new model (model II) to be estimated would be:

$$
\begin{aligned}
\mathrm{D}_{\mathrm{it}}= & \alpha \cdot \beta_{1}+(1-\alpha) \cdot \mathrm{D}_{\mathrm{i}, \mathrm{t}-1}+\alpha \cdot \beta_{2} \cdot \mathrm{NDTS}_{\mathrm{it}}+\alpha \cdot \beta_{3} \cdot \mathrm{GO}_{\mathrm{it}}+\alpha \cdot \beta_{4} \cdot \mathrm{I}_{\mathrm{it}} \\
& +\alpha \cdot \beta_{5} \cdot \mathrm{IN}_{\mathrm{it}}+\alpha \cdot \beta_{6} \cdot \mathrm{AG}_{\mathrm{it}}+\alpha \cdot\left(\beta_{7}+\beta_{8} \cdot \mathrm{AI}_{\mathrm{it}}\right) \cdot \mathrm{CF}_{\mathrm{it}}+\mathrm{d}_{\mathrm{t}}+\eta_{\mathrm{i}}+\varepsilon_{\mathrm{it}}
\end{aligned}
$$

The dynamic model with predetermined variables was estimated by using first differences with a two-step generalised method of moments (GMM) using the Arellano and Bond (1991) estimator, as this model includes the lagged-dependent variable as an explanatory variable. We use the GMM to avoid problems of unobservable heterogeneity and endogeneity. Unobservable heterogeneity refers to omitted variables that affect the outcome of interest and are correlated with the covariates. We took into account the unobservable heterogeneity (such as the particular small firm idiosyncrasy) through the individual effect of the companies $\eta_{\mathrm{i}}$, which is assumed to be different for every company and constant over time. ${ }^{1}$ It was also evident from the specification of the model that endogeneity problems could arise in the regressors due to: (a) the time which normally elapses between making the decision to change the capital structure and its execution; and (b) the possible relationship between certain explanatory variables (for instance, investment) and the variable to be explained. As a result, all the right-hand side variables of the models lagged twice (or more) are included as instruments, ${ }^{2}$ which also allowed for the consideration of possible errors

\footnotetext{
1 This technique enables us to eliminate the potential biases in the resulting estimates due to correlation between unobservable heterogeneity $\eta_{\mathrm{i}}$ and the explanatory variables included in the study.

2 The GMM accounts for endogeneity by using instruments. Since our model is in first differences, values of the right-hand side variables lagged two periods are valid instruments, as proposed by
} 
in the measurement of the variables. Moreover, a set of tests are undertaken in our model to verify the degree of consistency and robustness of the results obtained. More specifically, Sargan's test of over-identifying restrictions, tests of absence of both first and second order autocorrelation of residuals, and Wald's test of joint significance of the regressors and the time dummies are carried out. The model was estimated using the Stata programme (version 9).

\section{Empirical evidence and discussion}

To check for potential misspecification of the models, we used $\mathrm{m}_{2}$ statistics, which tested for lack of second-order serial correlation in first-difference residuals. The results obtained did not allow us to reject the null hypothesis of absence of second-order serial correlation between the errors. However, because of the transformation, there was no lack of first-order serial correlation $\mathrm{m}_{1}$ in the differenced residual, although the errors in the model in levels were not serially correlated. Nor could we reject the null hypothesis of absence of correlation between the instruments and the error term of Sargan's test of over-identifying restrictions (see Table 5). Table 5 also shows the two contrasts of Wald's test. The former null hypothesis checks the joint significance of the explanatory variables $z_{1}$, whereas the second one $z_{2}$ checks the joint significance of the time dummies. Both results of Wald's test validated the proposed partial adjustment model.

In accordance with the specification of the model proposed, the results show that the coefficient of the level of indebtedness delayed 1 year $(1-\alpha)$ is significant. This coefficient (0.4194) measures the transaction costs, thus implying an adjustment speed of $\alpha=0.5806$. The results showed that the companies from the footwear sector had higher transaction costs than those reported by De Miguel and Pindado (2001) for Spanish companies in general (0.2095). The higher importance of the transaction costs of footwear companies may be due to the size of the companies studied. Thus, while De Miguel and Pindado based their results on large firms listed on the stock exchange, all the companies in our sample were small. The higher transaction costs may originate from greater asymmetric information and agency conflicts existing in small-sized enterprises between shareholders-owners and lenders, in addition to increasing both the moral hazard and adverse selection problems (Ang 1992). Moreover, these transaction costs are higher in small firms because they cannot benefit from economies of scale (Wijst and Thurik 1993; Berger and Udell 1998).

The results of the econometric analysis revealed the significance of the analysed coefficients of the financial variables. The results reveal that debt has an inverse relationship with NDTS, debt cost, firm age and cash flow and a direct relationship with growth opportunities and investment. In summary, while the negative coefficient of

\footnotetext{
Footnote 2 continued

Anderson and Hsiao (1982). However, the efficiency of the estimation can be significantly improved by using all the orthogonality conditions that exist between lagged values of the right-hand side variables and the first differences of the error term. We thus follow this estimation strategy, proposed by Arellano and Bond (1991), which consists of using all the right-hand side variables lagged twice or more as instruments in order to improve efficiency.
} 
Table 5 Estimation (299 companies, 1,206 observations; dependent variable: $\mathrm{D}_{\mathrm{it}}$ )

\begin{tabular}{lrr}
\hline Variable/test & \multicolumn{2}{c}{ Regression coefficients/statistic (p value) } \\
\cline { 2 - 3 } & \multicolumn{1}{c}{ Model I } & \multicolumn{1}{c}{ Model II } \\
\hline $\mathrm{D}_{\text {it }-1}$ & $0.4194^{*}(0.000)$ & $0.4228^{*}(0.000)$ \\
$\mathrm{NDTS}_{\text {it }}$ & $-0.1638^{*}(0.000)$ & $-0.2689^{*}(0.000)$ \\
$\mathrm{GO}_{\text {it }}$ & $1.1087^{*}(0.000)$ & $0.9867^{*}(0.000)$ \\
$\mathrm{I}_{\mathrm{it}}$ & $0.2235^{*}(0.000)$ & $0.2572^{*}(0.000)$ \\
$\mathrm{IN}_{\mathrm{it}}$ & $-0.0851^{*}(0,000)$ & $-0.0873^{*}(0.000)$ \\
$\mathrm{AG}_{\text {it }}$ & $-0.0113^{*}(0,000)$ & $-0.0153^{*}(0.000)$ \\
$\mathrm{CF}_{\text {it }}$ & $-0.5071^{*}(0.000)$ & $-0.4355^{*}(0.000)$ \\
$\mathrm{AI}_{\text {it }} \times \mathrm{CF}_{\text {it }}$ & & $1.2119^{*}(0.000)$ \\
$\mathrm{z}_{1}$ & $12180.81^{*}(0.000)$ & $67926.39^{*}(0.000)$ \\
$\mathrm{z}_{2}$ & $41.08^{*}(0.000)$ & $162.14^{*}(0.000)$ \\
$\mathrm{m}_{1}$ & $-4.72^{*}(0.000)$ & $-4.74^{*}(0.000)$ \\
$\mathrm{m}_{2}$ & $1.01(0.313)$ & $0.98(0.327)$ \\
Sargan & $183.69(0.843)$ & $204.98(0.850)$ \\
\hline $\mathrm{D}_{\mathrm{i}}$ & &
\end{tabular}

$\mathrm{D}_{\text {it }}$ denotes the ratio of the book value of long-term debt and the book value of equity plus the long-term debt; NDTS ${ }_{i t}$ denotes the non-debt tax shield measure as the ratio of the difference between earnings before taxes and the results of taxes paid divided by the tax rate, divided by total assets; $\mathrm{GO}_{\mathrm{it}}$ denotes the growth opportunities measure as the intangible assets to total assets; $\mathrm{I}_{\mathrm{it}}$ denotes the investment in net fixed assets measure as the ratio of the difference between net fixed assets in the current and previous periods, plus depreciation expenditure in the current period divided by total assets, $\mathrm{IN}_{\mathrm{it}}$ denotes the debt cost measure as the ratio of financial expenses between total debts, $A G_{i t}$ denotes the firm age, measured by the time elapsed between the creation date and the current year, $\mathrm{CF}_{\text {it }}$ denotes the cash flow measure as the ratio of the addition of earnings before interest and taxes and non-cash deductions (depreciations and provisions) divided by total assets and $\mathrm{AI}_{\mathrm{it}} \times \mathrm{CF}_{\text {it }}$ denotes the interaction between the dummy variable Asymmetric Information and the cash flow, previously defined

Other information needed to read this table is: (i) $\mathrm{p}$ values in parentheses, taking into account that heteroskedasticity consistent asymptotic errors are used for the regression coefficients; (ii) * indicates significance at the $1 \%$ level; (iii) $\mathrm{z}_{1}$ is a Wald test of the joint significance of the reported coefficients, asymptotically distributed as chi-square under the null of all regression coefficients are zero; $z_{2}$ is a Wald test of the joint significance on the time dummies, asymptotically distributed as chi-square under the null of all regression coefficients are zero; (iv) $\mathrm{m}_{\mathrm{i}}$ is a serial correlation test of order $i$ using residuals in first differences, asymptotically distributed as $\mathrm{N}(0,1)$ under the null of no serial correlation; (v) Sargan is a test of the over-identifying restrictions, asymptotically distributed as chi-square under the null of no relation between the instruments and the error term

the NDTSs and positive coefficient of tangibility are favourable to the arguments of the trade-off theory, the positive coefficient of growth opportunities and negative coefficient of debt cost, age and cash flows is consistent with the prediction of the pecking order theory. These results constitute a greater support for the pecking order theory which is consistent with the fact that our sample is comprised of small firms. Thus, the pecking order theory has more validity in this type of firm. This result support Sogorb (2005) who find that the financing of SMEs relies on internal resources instead of external means.

According to the trade-off theory, NDTSs presented a significant inverse relationship with indebtedness, thus confirming the hypothesis that NDTSs act as debt substitutes to reduce tax burdens (Wald 1999; Sogorb 2005; Huang and Song 2006). Our results, in line with the theoretical framework of the trade-off theory and findings reported in previous studies (Huang and Song 2006; Céspedes et al. 2010; Chakraborty 
2010; Kayo and Kimura 2010) revealed a direct relationship between investment in fixed assets and leverage. Therefore, for Spanish footwear companies, investment decisions and financing are inter-related. Thus, these types of business investments, in addition to increasing debt capacity, also serve as collateral, reducing lenders' risks of suffering the agency costs of debt.

Growth opportunities showed a significant direct relationship with leverage, supporting the pecking order theory. This may be due to two reasons: (a) investment opportunities give rise to strong financing needs which, ceteris paribus, will lead to the use of more debt, (b) the low level of indebtedness of Spanish footwear firms and the importance of R\&D investments in this sector (Business Strategies Survey). The positive relationship between growth opportunities and debt was due to a below critical level of indebtedness; hence, even in the case of assets with little value in the event of liquidation, lenders are willing to lend funds because investment in R\&D is essential for a highly competitive industry where investments in patents, trademarks, design, etc. are fundamental requirements for companies to survive in an increasingly globalised market. These results confirm those obtained by De Miguel and Pindado (2001), Goyal et al. (2002), Murray and Goyal (2003), Sogorb (2005) and Casson et al. (2007).

Our results also find, according to the pecking order theory, an inverse relationship between leverage with debt cost (Cuñat 1999; Barry et al. 2008) and firm age (Michaelas et al. 1999; Hall and Graham 2000; López and Sogorb 2008). As reported in many previous studies (Giannetti 2003; Chen 2004; Huang and Song 2006; Frank and Goyal 2009; Céspedes et al. 2010; Chakraborty 2010; Kayo and Kimura 2010), our results revealed an inverse relationship between cash flow and indebtedness, thus supporting the theoretical framework proposed in the pecking order theory. In other words, the companies in our sample, in order to avoid asymmetric information, preferred internally generated funds to external resources to finance their investment projects. Moreover, the results of model II indicate that, since the coefficient $\beta_{8}$ is significant, the level of asymmetric information influences the relationship of cash flow with the level of indebtedness. These results show that when there are problems of asymmetric information $\left(\beta_{7}=-0.4355\right)$, the firms prefer internal to external financing, which supports the pecking order theory. On the contrary, in absence of asymmetric information $\left(\beta_{7}+\beta_{8}=-0.4355+1.2119=0.7764\right)$, the relationship between cash flow and leverage is positive, supporting the trade-off theory. Then, in absence of asymmetric information, firms with positive cash flows will prefer debt because (a) they want to maintain their optimal capital structure; (b) they have greater needs to shield this cash flow from corporate tax and (c) they are concerned about the problem of over-investments, which means that they issue debt in order to discipline the firm's managers.

\section{Conclusions}

This study examined the validity of the trade-off theory and the pecking order theory to explain the capital structures of a sample of small-sized firms of the Spanish footwear sector. As potential determinants of the firm leverage we consider debt level of the 
previous year, NDTS, growth opportunities, tangibility of assets, debt cost, age and cash-flow.

The empirical evidence obtained indicates that small businesses face high transaction costs, which are derived from typical agency problems and financial restrictions in capital markets. The existence of such high transaction costs justifies the gap between the target debt level and the current level of debt, together with a very slow approach to the target debt level.

The results show that debt level has an inverse relationship with NDTS and direct relationship with investment in fixed assets, supporting the trade-off theory. However, the positive coefficient of growth opportunities and negative coefficients of debt cost, age and cash flows is consistent with the prediction of the pecking order theory. These results are partially consistent with both theories, but provide evidence of the predominance of the pecking order theory over the trade-off theory when greater problems of information asymmetries exist, which is more usual in the small-sized firms.

Growth opportunities evidenced a direct relationship with leverage. This is not surprising due to the need to finance these investment opportunities with debt because rapidly growing firms are likely to have insufficient earnings to finance all of their growth internally. Furthermore, the low debt level of companies in the Spanish footwear sector also help to explain this direct relationship due to the importance of R\&D investments for this industry, valued as strategic investments by lenders.

Finally, the inverse relationship between cash flow and debt level, in presence of asymmetric information, supports the pecking order theory. This evidence reinforces the idea that higher information asymmetries in small firms provide greater validity for the pecking order theory in this type of firm. In absence of asymmetric information, the relationship between cash flow and leverage becomes positive, supporting the trade-off theory.

Acknowledgments The authors would like to thank the University of La Rioja (API07/A19) for its financial support.

Open Access This article is distributed under the terms of the Creative Commons Attribution License which permits any use, distribution, and reproduction in any medium, provided the original author(s) and the source are credited.

\section{References}

Acedo MA, Rodríguez JE (2003) Estudio empírico del endeudamiento, coste de la deuda y rentabilidades de la industria de calzado de La Rioja. Comparación por tamaño y sector. Cuadernos de Gestión 3(1-2):123-142

Anderson TW, Hsiao C (1982) Formulation and estimation of dynamic models using panel data. J Econom $18: 47-82$

Ang J (1992) On the theory of finance for privately held firms. J Small Bus Finance 1(3):185-203

Arellano M, Bond S (1991) Some tests of specification for panel data: Monte Carlo evidence and an application to employment equations. Rev Econ Stud 58:277-297

Barry CB, Mann SC, Mihov VT, Rodriguez M (2008) Corporate debt issuance and the historical level of interest rates. Financial Manag 37:413-430

Barton SL, Hill NC, Sundaram S (1989) An empirical test of stakeholder theory predictions of capital structure. Financial Manag 18(1):36-44 
Berger AN, Udell GF (1998) The economics of small business finance: the role of private equity and debt markets in the financial growth cycle. J Bank Finance 22:613-673

Boot A (2000) Relationship banking: what do we know? J Financial Intermed 9:26-56

Booth L, Aivazian V, Demirgüc-kunt A, Maksimovic V (2001) Capital structure in developing countries. J Finance 56:87-130

Bougheas S, Mizen P, Yalcin C (2006) Access to external finance: theory and evidence on the impact of monetary policy and firm-specific characteristics. J Bank Finance 30(1):199-227

Bradley M, Jarrell GA, Kim EH (1984) On the existence of an optimal capital structure: theory and evidence. J Finance 34(3):857-880

Cassar G, Holmes S (2003) Capital structure and financing of SMEs: Australian evidence. Account Finance 43:123-147

Casson PD, Roderick M, Nisar TM (2007) The financing decisions of innovative firms. Res Int Bus Finance 22(2):208-221

Céspedes J, González M, Molina C (2010) Ownership and capital structure in Latin America. J Bus Res 63:248-254

Chakraborty I (2010) Capital structure in an emerging stock market: the case of India. Res Int Bus Finance 24:295-314

Chaplinsky S, Niehaus G (1993) Do inside ownership and leverage share common determinants? Q J Bus Econ 32(3):51-65

Chen JJ (2004) Determinants of capital structure of Chinese-listed companies. J Bus Res 57:1341-1351

Cuñat V (1999) Determinantes del plazo de endeudamiento de las empresas españolas. Investig Econ 23(3):351-392

De Miguel A, Pindado J (2001) Determinants of capital structure: new evidence from Spanish panel data. J Corp Finance 7:77-99

Deangelo H, Masulis R (1980) Optical capital structures under corporate and personal taxation. J Financial Econ 8:3-29

Deesomsak R, Paudyal K, Pescetto YG (2004) The determinants of capital structure: evidence from the Asia Pacific region. J Multinatl Financial Manag 14:387-405

Diamond D (1989) Reputation acquisition in debt markets. J Political Econ 7(4):828-862

Fama EF, French KR (2002) Testing trade-off and pecking order predictions about dividends and debt. Rev Financial Stud 15:1-33

Frank M, Goyal V (2000) Testing the pecking order theory of capital structure. J Financial Econ 67(2):217248

Frank M, Goyal V (2009) Capital structure decisions: which factors are reliably important? Financial Manag 38:1-37

Gaud P, Jani E, Hoesli M, Bender A (2005) The capital structure of Swiss companies: an empirical analysis using dynamic panel data. Eur Financial Manag 11:51-69

Giannetti M (2003) Do better institutions mitigate agency problems? Evidence from corporate finance choices. J Finance Quant Anal 38:185-212

González V, González F (2007) Firm size and capital structure: evidence using dynamic panel data. Documentos de Trabajo Funcas 340:1-36

Goyal V, Lehn K, Racic S (2002) Growth opportunities and corporate debt policy: the case of the U.S. defence industry. J Financial Econ 64:15-37

Graham J, Harvey C (2001) The theory and practice of corporate finance: evidence from the field. J Financial Econ 60:187-243

Hall P, Graham N (2000) Industry effects on the determinants of unquoted SMEs' capital structure. Int J Econ Bus 7(3):297-312

Harris M, Raviv A (1991) The theory of capital structure. J Finance 56(1):297-355

Huang G, Song FM (2006) The determinants of capital structure: evidence from China. China Econ Rev $17: 14-36$

Jalilvand A, Harris RS (1984) Corporate behaviour in adjusting to capital structure and dividend targets: an econometric study. J Finance 39:127-145

Jensen G, Solberg D, Zorn T (1992) Simultaneous determination of insider ownership, debt and dividend policies. J Financial Quant Anal 27:247-261

Jensen M (1986) Agency cost of free cash flow, corporate finance and takeovers. Am Econ Rev 76:323-329

Kayo E, Kimura H (2010) Hierarchical determinants of capital structure. J Bank Finance 35(2):358-371 
Lemmon ML, Roberts MR, Zender JF (2008) Back to the beginning: persistence and the cross-section of corporate capital structure. J Finance 63:1575-1608

Lewellen WG, Badrinath SG (1997) On the measurement of Tobin's q. J Financial Econ 44:77-122

Lööf H (2004) Dynamic optimal capital structure and technical change. Struct Change Econ Dyn 15:449_ 468

López J, Aybar C (2000) An empirical approach to the financial behaviour of small and medium sized companies. Small Bus Econ 14:55-63

López J, Sogorb F (2008) Testing trade-off and pecking order theories financing SMEs. Small Bus Econ 31:117-136

López J, Romero M (1997) Estudio comparado de la estructura financiera de la pyme en la Unión Europea. Actualidad Financiera 2:49-59

Maroto JA (1996) Estructura financiera y crecimiento de las Pymes. Economía Industrial 310:29_40

Mcclure KG, Clayton R, Hofler RA (1999) International capital structure differences among the G7 nations: a current empirical view. Eur J Finance 5:141-164

Michaelas N, Chittenden F, Poutziouris P (1999) Financial policy and capital structure choice in UK SMEs: empirical evidence from company panel data. Small Bus Econ 12:113-130

Miller MH (1977) Debt and taxes. J Finance 32:261-275

Modigliani F, Miller MH (1958) The cost of capital, corporation finance and the theory of investment. Am Econ Rev 48:261-297

Modigliani F, Miller MH (1963) Taxes and the cost of capital: a correction. Am Econ Rev 53:433-443

Murray F, Goyal V (2003) Testing the pecking order theory of capital structure. J Financial Econ 67(2):217248

Myers S (1977) Determinants of corporate borrowing. J Financial Econ 5:147-175

Myers S (1984) The capital structure puzzle. J Finance 34:575-592

Myers S, Majluf N (1984) Corporate financing and investment decisions when firms have information that investors do not have. J Financial Econ 13:187-221

Rajan RG, Zingales L (1995) What do we Know about capital structure? Some evidence from international data. J Finance 50(4):1421-1460

Ross SA, Westerfield RW, Jaffe J (2008) Corporate finance, 8th edn. McGraw-Hill Irwin, New York

Shyam-Sunder L, Myers S (1999) Testing static trade-off against pecking order models of capital structure. J Financial Econ 51:219-244

Sogorb F (2005) How SME uniqueness affects capital structure: evidence from a 1994-1998 Spanish data panel. Small Bus Econ 25:447-457

Taggart R (1985) A model of corporate financing decisions. J Finance 32:1467-1484

Titman S, Wessels R (1988) The determinants of capital structure choice. J Finance 43:1-19

Van Horne J (1977) Financial management and policy. Prentice-Hall, Englewood Cliffs

Wald JK (1999) How firm characteristics affect capital structure: an international comparison. J Financial Res 22(2):161-187

Wijst N, Thurik R (1993) Determinants of small firms debt ratios: an analysis of retail panel data. Small Bus Econ 5:55-65 